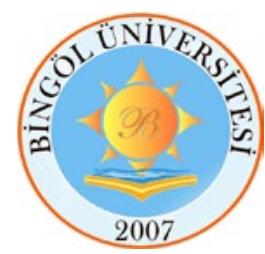

Bingöl Üniversitesi

İktisadi ve Idari Bilimler Fakültesi

Bingol University

Journal of Economics and Administrative Sciences

Cilt/Volume: 5, Say1/Issue: 1

Y1l/Year: 2021, s. 337-364

DOI: $10.33399 /$ biibfad. 868418

ISSN: 2651-3234/E-ISSN: 2651-3307

Bingöl/Türkiye

Makale Bilgisi/Article Info

Geliş/Received: 26.01 .2021

Kabul/Accepted: 30.06.2021

\title{
CRITIC TEMELLİ CODAS VE ROV YÖNTEMLERİ İLE AB ÜLKELERİ YAŞAM KALITESİ ANALIZİ
}

\section{Analysis of Life Quality of EU Countries with CRITIC based CODAS and ROV Methods}

Eda ÇINAROĞLU*

Öz

Bu çalışmada Avrupa Birliği (AB) üye ülkeleri yaşam kalitesi analizi çok kriterli karar verme (ÇKKV) tekniklerinden CRITIC, CODAS ve ROV yöntemlerinin kullanımı ile gerçekleştirilmiştir. Ülkelere ait yaşam kalitesi değerlendirme sürecinde satın alma gücü indeksi, iklim indeksi, yaşam maliyeti indeksi, güvenlik indeksi, sağlık hizmeti indeksi, emlak fiyatları/gelir oranı, kirlilik indeksi ve trafikte harcanan süre indeksi kriterleri esas alınmıştır. Veriler Numbeo adlı internet sitesinden edinilmiş olup, 2020 yılı kasım ayı değerleridir. Kriter ağırlıklarının belirlenmesi aşamasında CRITIC yöntemi kullanılmış, yaşam kalitesi değerlendirme sürecine ait en fazla önem arz eden kriterin yaşam maliyeti indeksi olduğu belirlenmiştir. Ülkelerin yaşam kalitesi açısından değerlendirilmesi aşamasında ise CODAS ve ROV yöntemlerinin kullanımı tercih edilmiş olup, her iki yöntem ile de yaşam kalitesi düzeyinin en yüksek olduğu ülkenin Danimarka olduğu belirlenmiştir. Bu sonuç Danimarka'nın yaşam maliyeti indeksi değerinin minimum olması ile örtüşmektedir. Yine her iki yöntem ile elde

\footnotetext{
* Dr. Öğr. Üyesi, Erciyes Üniversitesi, Havacılık ve Uzay Bilimleri Fakültesi, Havacılık Yönetimi Bölümü, Kayseri, Türkiye, ecinaroglu@erciyes.edu.tr, ORCID: https:/ /orcid.org/0000-0002-2904-3376.
} 
edilen sonuçlar yaşam kalitesi düzeyinin en düşük olduğu ülkenin Yunanistan olduğuna işaret etmektedir.

Anahtar Kelimeler: Çok kriterli karar verme (ÇKKV), CRITIC, CODAS, ROV, yaşam kalitesi

Jel Kodlarn: C30; C44; D81; N30

\begin{abstract}
The quality of life analysis of European Union (EU) member countries is carried out in this study by using CRITIC, CODAS and ROV methods, which are among the multicriteria decision making (MCDM) methods. In the evaluation process of the quality of life of the countries, purchasing power index, climate index, cost of living index, safety index, health service index, property prices/income ratio, pollution index and time spent in traffic index criteria are used. The data is obtained from the website called Numbeo and they are November 2020 values. The CRITIC method has been used to determine the criteria weights and it is determined that the most important criterion of the quality of life assessment process is the cost of living index. The CODAS and ROV methods have preferred in the evaluation phase of the countries in terms of quality of life, and it is found out that the country with the highest quality of life is Denmark with both methods. This result is consistent with Denmark's minimum value of the cost of living index. Again, the results obtained with both methods indicate that the country with the lowest quality of life is Greece.
\end{abstract}

Keywords: Multi-criteria decision making (MCDM), CRITIC, CODAS, ROV, quality of life

Jel Codes: C30; C44; D81; N30

\title{
1. Giriş
}

Yaşamın gayesi, önemi, kalitesi ve mutluluk gibi kavramlar düşünürlerin sürekli ilgisini çeken konu başlıkları olmuştur. Yaşam kalitesi kavramının kökenlerinin Antik Yunan dönemine kadar uzandığ1 söylenmektedir. Bu denli eski bir kavramın her dönemin koşullarına ve ilgili dönemde esas alınan bakış açılarına göre farklı biçimlerde yorumlandığı bilinmektedir. Bu açıdan, kavramın uzlaşık tek bir tanımının var olmadığı ve araştırmacılara dinamik ve geniş bir içerik sunduğu ifade edilebilir (Sarı ve Kindap, 2018: 44). 
Yaşam kalitesi kavramı hem öznel, hem de nesnel ölçütler ile değerlendirilebilen ve geniş anlamlar içeren bir nitelik taşımaktadır. Yapılan araştırmalar teknolojik gelişme ve gelir düzeyi artışının yaşam kalitesinin iyileşmesi adına tek bir gösterge olmadı̆̆ını; toplumsal, mekânsal ve siyasal pek çok etkenin yaşam kalitesi üzerinde önem arz ettiğini işaret etmektedir. Yani toplumsal, ekonomik ve çevresel kalite kavramları entegre biçimde yaşam kalitesinin belirleyici unsurlarıdır (Pacione, 2003: 19).

Ülkeler açısından ele alındığında sağlık, güvenlik gibi boyutlar kavramın öznel bileşenlerini teşkil ederken; satın alma gücü, yaşam maliyeti, emlak fiyatları, kirlilik ya da iklim boyutları ise yaşam kalitesinin nesnel boyutlarını oluşturmaktadır. Ekonomik kalkınma düzeyi, emlak fiyatları, sağlık, eğitim, güvenlik, çevre, fırsat eşitliği, cinsiyet eşitliği gibi göstergeler ülkelerin yaşam kalitesinin analizinde ele alınabilecek göstergeler arasında sayılabilir (Koçak, 2009: 143).

Ülkelerin yaşam kalitesi değerlendirmesinde birden fazla göstergenin dikkate alınması gereği ÇKKV yöntemlerinin kullanımını uygun kılmaktadır. ÇKKV, yöneylem araştırması modelleri sınıfının en hızla gelişen dalıdır. ÇKKV, karar vericiye problemini pek çok boyutta değerlendirme ve bu boyutlar açısından en yüksek düzeyde memnuniyeti beraberinde getiren en iyi alternatifi seçme imkânı sağlayan yöntemler bütünüdür (Chatterjee ve Chakraborty, 2012: 385).

Çalışmada, AB ülkelerinde yaşam kalitesi analizi amaçlanmıştır. Değerlendirme sürecinde satın alma gücü indeksi, sağlık hizmeti indeksi, yaşam maliyeti indeksi, güvenlik indeksi, iklim indeksi, emlak fiyatları/gelir oranı, kirlilik indeksi ve trafikte harcanan süre indeksi kriterleri esas alınmıştır. Numbeo isimli internet sitesi 2020 yılı kasım ayı verileri analize dahil edilmiştir. Kriter ağırlıklarının belirlenmesi aşamasında CRITIC (CRiteria Importance Through Intercriteria Correlation) yöntemi kullanılmış olup; ülkelerin yaşam kalitesi açısından sıralanması aşamasında ise CODAS (COmbinative Distancebased ASsessment) ve ROV (Range of Values) yöntemlerinin kullanımı tercih edilmiştir.

Giriş bölümü sonrasında konu ile ilgili literatür taramasına yer verilmiştir. Sonraki bölüm yöntemlerin açıklanması ve uygulama 
adımlarını içermektedir. Analiz bölümünde CRITIC yöntemi kullanımı ile kriter ağırlıkları belirlenmiş, sonrasında CODAS ve ROV yöntemleri kullanımı ile ülkelerin sıralaması elde edilmiştir. Son bölüm sonuç ve değerlendirmeleri içermektedir.

\section{Literatür}

CRITIC yönteminin kriter ağırlıklarının belirlenmesi amacıyla diğer ÇKKV yöntemleri ile entegre biçimde kullanıldığı pek çok çalışma literatürde yer almaktadır. Son döneme ait bazı çalışmalar şu şekilde özetlenebilir: Ahmad, Bingöl ve Wakeel (2020), CRITIC ve MABAC yöntemleri ile esnek üretim sistemlerinde robot seçimi kararı vermiş; Akbulut (2020), bütünleşik CRITIC ve MABAC yöntemleri ile finansal performans ve pay senedi getirisi arasındaki ilişkiyi ölçümlemiş; Altın (2020), CRITIC, Entropi, TOPSIS ve MAUT yöntemleri ile ekonomik özgürlük indeksini analiz etmiş; Apan ve Öztel (2020) bütünleşik CRITIC ve PROMETHEE yöntemleri ile girişim sermayesi yatırım ortaklıklarının finansal performansını değerlendirmiş; Aydın (2020), CRITIC destekli MAIRCA yöntemleri ile kamu sermayeli bankaların performans analizini gerçekleştirmiş; Lamas, Castro-Santos ve Rodriguez (2020), CRITIC, Entropi, standart sapma ve varyans yöntemleri ile bir dizel deniz motorunun performans ve emisyonlarını analiz etmek amacıyla sayısal model geliştirmiş; Nguyen vd., (2020), CRITIC destekli Gri Sistem Teorisi ile ülkelerdeki elektrikli otomobil satış performansını irdelemiş ve sıralamasını elde etmiş; Yılmaz ve Söyük (2020), CRITIC, ortalama ağırlık, TOPSIS ve EDAS yöntemleri ile ülkelerin sağlık durumu göstergelerini kıyaslamışlardır.

Literatürde ÇKKV problemlerinde sıralama ve en iyi alternatifi bulma amacıyla CODAS yönteminin başarıyla uygulandığı çalışmalar mevcuttur. Son döneme ait yayınlardan bazıları şunlardır: Abdali, Sahebi ve Pishvaee (2021), iklimsel, ekolojik ve sosyal kriterlere göre şeker kamışı yetiştiriciliğine en uygun bölgeleri bulmak için hibrit BWM ve CODAS yöntemlerini kullanmış; Alioğulları ve Tüysüz (2020), Entropi destekli EDAS ve CODAS yöntemleri ile İstanbul ilinin sektörel bazda diş ticaret kapasitesini incelemiş; Badi ve Kridish (2020), FUCOM destekli CODAS yöntemi ile Libya'da düzenli depolama sahası seçimi gerçekleştirmiş; Donyaii, Sarraf ve Ahmadi (2020), su 
kaynakları yönetim araçlarının kullanımı çerçevesinde optimum rezervuar işletimi seçimi üzerine odaklanmış; Deveci, Cin ve Kağızman (2020), bulanık CODAS yöntemi ile Türkiye'deki yenilenebilir enerji alternatiflerini analiz etmiş; Kiracı ve Bakır (2020), CRITIC destekli CODAS yöntemi ile Star Alliance üyesi havayolu işletmelerinin performansını değerlendirmiş; Remadi ve Frikha (2020), belirsizlik altında yeşil malzeme seçimi için bir ÇKKV modeli geliştirmiş; Ulutaş (2020b), bir Türk mobilya atölyesi için tedarikçi seçim problemini ele alarak BWM ve bulanık CODAS'ı içeren entegre bir ÇKKV modeli önermiş; Ulutaş (2020c), SWARA destekli CODAS yöntemi ile kargo şirketi seçimi gerçekleştirmiş; Zaralı (2020), CRITIC destekli CODAS yöntemini ağır ticari araç seçimi problemine uygulamıştır.

ROV yönteminin ÇKKV problemlerinde alternatiflerin değerlendirilmesi ve sıralanması amacıyla kullanımını içeren farklı çalışmalar mevcuttur. Yöntemin kullanıldığı yayınlardan örnekler şu şekilde siralanabilir: Wakeel vd., (2020), Entropi destekli ROV yöntemi ile bir yariiletken endüstrisinde tedarikçi seçimini gerçekleştirmiş; Ulutaş (2020a), bir giyim tekstil firması için en uygun dikiş makinesini seçmek için Gri AHP ve ROV'u içeren entegre bir ÇKKV modeli geliştirmiş; Akın (2019), makine alım probleminde Entropi-ROV ile CRITIC-ROV yöntemlerini karşılaştırmış; Özdağoğlu ve Keleş (2019), Gri Entropi destekli ROV yöntemi kullanarak BİST'de işlem gören futbol kulüplerine ait finansal performans analizini gerçekleştirmişlerdir.

Aşağıda, çalışmanın konusunu teşkil eden, ülkelerde yaşam kalitesi analizinin farklı yöntemler kullanılarak gerçekleştirildiği çalışmalardan örnekler sunulmuştur:

Yıldız vd., (2019), 31 AB ülkesinin yaşam kalitesini analiz etmişlerdir. Sağlık, eğitim, barınma, güvenlik, sosyal ilişkiler, çalışma durumu, yaşam koşulları, çevre ve yönetim şeklinde sıralanabilecek kriterlerin esas alındığı çalışmada metodoloji olarak Pisagor bulanık AHP ve TOPSIS kullanılmıştır. Değerlendirme sürecinde en yüksek önem değerine sahip kriterin sağlik kriteri olduğu belirlenmiştir. 
Sonuçlar yaşam kalitesi açısından ilk sıralarda yer alan ülkelerin Norveç ve Danimarka olduğunu göstermektedir.

Ayyıldız ve Demirci (2018), SWARA destekli TOPSIS yöntemini kullanarak Türkiye'deki 81 ili yaşam kalitesi açısından değerlemeye tabi tutmuşlardır. Yaşam kalitesi ile ilgili TUIK tarafından belirlenen 41 farklı gösterge gruplandırılarak 11 kriter şeklinde analize dahil edilmiştir. Bu kriterler servet ve gelir, altyapı hizmetleri erişim düzeyi, güvenlik, konut, çalışma hayatı, eğitim, çevre, sağlık, sosyal yaşam, yaşam memnuniyeti ve sivil katılım şeklindedir. Sonuçlar yaşam kalitesinin yüksek olduğu şehirlerin ülkenin batı kesiminde yer aldığını işaret etmektedir. Üç büyük şehir İstanbul, Ankara ve İzmir ilk sıralarda yer almaktadır. Bu bağlamda ekonomik açıdan gelişmiş olan şehirlerde yaşam kalitesinin daha yüksek olduğu ifade edilmiştir.

Ömürbek, Eren ve Dağ (2017), Entropi, ARAS ve MOOSRA yöntemlerini entegre kullanarak $A B$ ülkelerinin yaşam kalitesi analizini gerçekleştirmişlerdir. Kirlilik, satın alma gücü ve yaşam maliyetinin yaşam kalitesi kıyasında en önemli kriterler olduğu saptanan çalışmada, her iki değerlendirme sonucunda da yaşam kalitesi açısından en iyi olan ülke Finlandiya olarak bulunmuştur.

Orakçı ve Özdemir (2017), Türkiye ve AB ülkelerinin insani gelişmişlik düzeyi açısından kıyasını amaçladıkları çalışmalarında gri ilişkisel analiz ve MOORA yöntemlerini kullanmışlardır. Kriterlere ait önem düzeylerinin CRITIC ve Entropi yöntemleri ile belirlendiği uygulamada, her iki nesnel ağırlıklandırma yöntemine göre en fazla önem arz eden kriterin ev kira ücretleri olduğu tespit edilmiştir. İnsani gelişmişlik düzeyi açısından en önde gelen ülkeler gri ilişkisel analiz ve MOORA-Oran yöntemi bulgularına göre Lüksemburg, Avusturya ve Finlandiya iken; MOORA-Referans noktası yaklaşımı yöntemi bulgularına göre ise Birleşik Krallık, Danimarka ve Hollanda'dır.

Shahrokhi Sardoo ve Nooripoor (2014), İran'da Jiroft şehrinin ilçelerinde yaşam kalitesinin analizini amaç edinmişlerdir. Çalışmada TOPSIS tekniği, yaşam kalitesi kriterlerini ağırlıklandırmak ve ardından kırsal bölgelerin merkezlerini sıralamak için kullanılmıştır. Gelir kriterinin yaşam kalitesi açısından en önemli belirleyici olduğu belirlenmiştir. 
Kaya, Çetin ve Kuruüzüm (2011), AB ve aday ülkelerin 2003 yılı, 2005 yılı ve 2007 yılına ilişkin yaşam kalitesi analizini VIKOR yöntemi kullanımı ile gerçekleştirmişlerdir. Çalışmada aile, barınma, boş zaman, çevre, eğitim, gelir yoksunluğu, güvenlik, istihdam, sağlik, sosyal katılım, ulaşım, yaşam tatmini gibi temel göstergeler esas alınmıştır. 2003 ve 2007 yıllarında yaşam kalitesi açısından en iyi seviyede olan ülkenin İspanya olduğu sonucuna ulaşılmış olup, 2005 yılında ise yaşam kalitesi en yüksek olan ülkelerin Danimarka ve İsveç olduğu belirlenmiştir. İlgili yıllarda Türkiye'nin listenin son sıralarında yer aldığ

Rahman, Mittelhammer ve Wandscheider (2005), dünyanın 43 ülkesinin yaşam kalitesi açısından resmedilmesini amaçladıkları çalışmalarında aile ve arkadaşlarla ilişki, duygusal refah, maddi refah, sağlık, iş ve üretkenlik, kendini topluluğun bir parçası hissetme, yaşam kalitesi, çevre kalitesi ve kişisel güvenlik gibi ölçütleri esas almışlardır. Borda kuralı yaklaşımı temelinde, ülkeler arası kıyasa yönelik yaşam kalitesi endeksi olarak kullanılabilecek, faktör endeksleri tanımlamaya çaba göstermişlerdir.

Literatür taraması sonucunda yaşam kalitesi kıyasında CRITIC, CODAS ve ROV yöntemlerinin kullanımını içeren bir çalışma göze çarpmamıştır. Bu açıdan ilgili yöntemlerin kullanıldığı bu çalışmanın literatüre katkı sağlayacağı ümit edilmektedir. Yine farklı ÇKKV teknikleri ile ulaşılan sıralama sonuçlarının QLI (quality life index) değerleri ile kıyasının çalışmaya özgünlük kattığı düşünülmektedir.

\section{Yöntem}

\subsection{CRITIC Yöntemi}

ÇKKV problemlerinde temel noktalardan birisi kriterlerin önem düzeylerinin belirlenmesidir. Kriterlerin ağırlılarını belirleme prosedürleri yıllardır araştırma ve bilimsel tartışma konusu olmuştur. Literatürde kriter ağırlıklarını tanımlamak için geliştirilmiş farklı yaklaşımlar yer almaktadır. Bu yaklaşımlar temel olarak öznel ve nesnel olarak ikiye ayrılır. Öznel yaklaşımlar karar vericinin yargılarını içerirken, nesnel yaklaşımlar çeşitli matematiksel modeller kullanilarak karar matrisinde yer alan bilgilerden hareketle kriter 
ağırlıklarının belirlenmesine dayanır. Kriter ağırlıklarının karar verme sürecinin sonucunu önemli ölçüde etkileyebileceği gerçeği göz önüne alındığında, bu sürecin objektifliğine özel dikkat gösterilmesi gereği ortaya çıkmaktadır (Vujičić, Papić ve Blagojević, 2017: 422).

CRITIC (CRiteria Importance Through Intercriteria Correlation) yöntemi, ÇKKV problemlerinde kriterlere ait önem düzeylerinin objektif biçimde belirlenmesi amacıyla Diakoulaki, Mavrotas ve Papayannakis (1995) tarafından geliştirilmiş olan bir tekniktir. Ulaşılan ağırlıklar, problemin yapısında bulunan kontrast yoğunluğu ve çatışmayı içerir (Diakoulaki, Mavrotas ve Papayannakis, 1995: 765). Yöntemde karar matrisi değerlendirilir ve ağırlıklandırmada kriter karşıtlı̆̆ını belirlemek için normalleştirilmiş kriter değerlerinin sütunlara göre standart sapması ve tüm sütun çiftlerinin korelasyon katsayıları kullanılır (Madić ve Radovanović, 2015: 195). Yani kriter ağırlıklarının belirlenmesi aşaması hem kriterin standart sapmasını, hem de diğer kriterler arasındaki korelasyonunu içerir. Standart sapma değeri yüksek, diğer kriterler ile arasındaki korelasyon katsayısı düşük olan kriter karar probleminde en yüksek önem düzeyine sahip olur.

CRITIC yöntemi ile çözüm süreci aşağıda yer alan 5 adımdan oluşmaktadır (Diakoulaki, Mavrotas ve Papayannakis, 1995: 765; Akçakanat, Aksoy ve Teker, 2018: 6).

Adım 1. Karar matrisinin tesisi

Birinci adımda $\mathrm{n}$ tane karar alternatifi ile $\mathrm{m}$ tane değerlendirme kriteri içeren karar problemine ilişkin karar matrisi Eşitlik (1)'deki gibi tesis edilir.

$$
X=\left[X_{i j}\right]_{n * m}=\left[\begin{array}{cccc}
X_{11} & X_{12} & \cdots & X_{1 m} \\
X_{21} & X_{22} & \cdots & X_{2 m} \\
\cdot & \cdot & \cdot & \cdot \\
\cdot & \cdot & \cdot & \cdot \\
\cdot & \cdot & \cdot & \cdot \\
X_{n 1} & X_{n 2} & \cdots & X_{n m}
\end{array}\right]
$$




\section{Adım 2. Normalize karar matrisinin tesis edilmesi}

İkinci adımda kriterlere ait değerlerin ortak bir birime çevrilmesi adına kriterin türünü esas alarak karar matrisi normalize edilir. Maksimizasyon yönü içeren fayda nitelikli kriterler için Eşitlik (2), minimizasyon yönü içeren maliyet nitelikli kriterler için ise Eşitlik (3) kullanilır.

$r_{i j}=\frac{x_{i j}-x_{j}^{\min }}{x_{j}^{\max }-x_{j}^{\min }}$

$r_{i j}=\frac{x_{j}^{\max }-x_{i j}}{x_{j}^{\max }-x_{j}^{\min }}$

Eşitliklerde yer alan $x_{j}^{\text {min }} \mathrm{j}$. kriterin alternatifler içerisindeki minimum değerini, $x_{j}^{\max }$ ise $\mathrm{j}$. kriterin alternatifler içerisindeki maksimum değerini ifade etmektedir.

Adım 3. Kriterler arasındaki ilişki düzeyinin belirlenmesi

Normalize edilmiş karar matrisi elemanları kullanılarak $\mathrm{j}$ ve $\mathrm{k}$ kriterleri arasındaki korelasyon katsayısı değerleri Eşitlik (4) yardımı ile hesaplanır. Bu eşitlikte yer alan $\overline{r_{j}} \mathrm{j}$. kritere ait ortalama değeri ifade etmektedir.

$P_{j k}=\frac{\sum_{i=1}^{m}\left(r_{i j}-\overline{r_{j}}\right)\left(r_{i k}-\overline{r_{k}}\right)}{\sqrt{\sum_{i=1}^{m}\left(r_{i j}-r_{j}\right)^{2} \sum_{i=1}^{m}\left(r_{i k}-r_{k}\right)^{2}}}$

Adım 4. Kriterlere ait bilgi miktarı değerlerinin $\left(C_{J}\right)$ hesaplanması

$C_{J}=\sigma_{J} \sum_{k=1}^{n}\left(1-P_{j k}\right)$

Bu adımda her bir kritere ait bilgi miktarı $\left(C_{J}\right)$ Eşitlik (5) kullanımı ile belirlenir. Eşitlikte yer alan $\sigma_{J}$ ifadesi j. kritere ait standart sapma değeri olup, Eşitlik (6) ile hesaplanmaktadır.

$\sigma_{j}=\sqrt{\frac{\sum_{i=1}^{m}\left(r_{i j-} \overline{r_{j}}\right)^{2}}{m}}$

Adım 5. Kriter ağırlıkları tespiti

Son adımda her kritere ait $C_{j}$ değeri tüm kriterlere ait $C_{j}$ değerleri toplamına oranlanarak ilgili kriter için ağırlık değeri saptanmaktadır. Eşitlik (7) bu işlemi ifade etmektedir. 
$w_{j}=\frac{C_{j}}{\sum_{k=1}^{2} C_{k}}$

\subsection{CODAS Yöntemi}

CODAS (Combinative Distance-based Assessment) Birleşik Mesafe Tabanlı Değerlendirme Yöntemi olarak bilinen ÇKKV yöntemlerinden birisidir. Ghorabaee vd., tarafından 2016 yılında geliştirilmiştir. Negatif ideal çözüme en uzak olan alternatifin en iyi alternatif olduğu fikri yöntemin temelini oluşturmaktadır. Değerlendirme sürecinde karar alternatiflerine ait negatif ideal çözüm uzaklık değerleri Öklid ve Taxicab uzaklık formülleri ile hesaplanır. Dikkate alınan birincil ölçü Öklid uzaklığıdır. İki karar alternatifinin benzer Öklid uzaklıklarına sahip olmaları durumunda ikincil ölçü olan Taxicab uzaklığı esas alınarak çözüm süreci tamamlanır. Yöntemin uygulama adımları şöyledir (Ghorabaee vd., 2016: 29-30).

Adım 1. Karar matrisi Eşitlik (1)'deki gibi tesis edilir.

Adım 2. Bu adım Normalize Karar Matrisi tesis edilmesi adımıdır. Normalizasyon işlemi esnasında kriter türü esas alınır. Maksimizasyon yönlü fayda nitelikli kriterler için Eşitlik (8), minimizasyon yönlü maliyet nitelikli kriterler için ise Eşitlik (9) kullanilır.

$n_{i j}=\frac{x_{i j}}{\max _{i} x_{i j}}$
$n_{i j}=\frac{\min _{i} x_{i j}}{x_{i j}}$

Adım 3. Bu adım Ağırlıklandırılmış Normalize Karar Matrisi oluşturulması adımıdır. Eşitlik (10) kullanılarak her bir kriterin kendisine ait önem ağırlığı ile çarpımı sonucu bu matris elde edilir.

$r_{i j}=w_{j} * n_{i j}$

Adım 4. Bu adım negatif ideal çözüm değerlerinin belirlenmesi adımıdır. Ağırlıklandırılmış Normalize Karar Matrisi'nin her sütünü için en küçük değer belirlenerek, kriterlere ait negatif ideal çözüm değerleri tespit edilir. Bu adımda Eşitlik (11)'den faydalanılır. 


$$
\begin{aligned}
& n s=\left\lfloor n s_{j}\right\rfloor_{1 * m} \\
& n s_{j}=\min _{i} r_{i j}
\end{aligned}
$$

Adım 5. Bu adım karar alternatiflerinin negatif ideal çözüme olan uzaklıklarının hesaplanması adımıdır. Uzaklık değerleri belirlenirken Eşitlik (12) ile formüle edilen Öklid uzaklık $\left(E_{i}\right)$ ve Eşitlik (13) ile formüle edilen Taxicab uzaklık $\left(T_{i}\right)$ ölçülerinden faydalanılır.

$$
\begin{aligned}
& E_{i}=\sqrt{\sum_{j=1}^{m}\left(r_{i j}-n s_{j}\right)^{2}} \\
& T_{i}=\sum_{J=1}^{m}\left|r_{i j}-n s_{j}\right|
\end{aligned}
$$

Adım 6. Bu adım Göreceli Değerlendirme Matrisi oluşturulması adımıdır. Göreceli Değerlendirme Matrisi oluşturulurken Eşitlik (14) ve Eşitlik (15) kullanımı ile her alternatifin Öklid $\left(E_{i}\right)$ ve Taxicab $\left(T_{i}\right)$ uzaklıkları dikkate alınır,

$R_{a}=\left\lfloor h_{i k}\right\rfloor_{n * n}$

$h_{i k}=\left(E_{i}-E_{k}\right)+\left(\psi\left(E_{i}-E_{k}\right) *\left(T_{i}-T_{k}\right)\right)$

Eşitlik (15)'de var olan $\psi$ değeri, karar alternatiflerinin Öklid uzaklık değerleri eşitliğinin tanımlanması için kullanılan bir eşik fonksiyonudur. Bu eşik fonksiyonu Eşitlik (16)'da tanımlanmıştır.

$\psi(x)=\left\{\begin{array}{l}1, \text { e g } e r|x|>\tau \\ 0, \text { ĕ } e r|x|<\tau\end{array}\right.$

Fonksiyon içerisinde yer alan $\tau$ değeri Taxicab $\left(T_{i}\right)$ uzaklığının hangi durumlarda hesaba katılması gerektiğini ifade eden bir eşik değeri olup; 0,01 ile 0,05 arasında değişen değerler almaktadır. Literatürde yaygın kullanım değerinin 0,02 olduğu ifade edilmektedir (Ghorabaee vd., 2016; Badi, Abdulshahed ve Shetwan, 2018; Boltürk, 2018; Mathew ve Sahu, 2018; Kiracı ve Bakır, 2020).

Adım 7. Bu adım her bir karar alternatifi için Değerlendirme Puanı $\left(H_{i}\right)$ hesaplama adımıdır. Eşitlik (17)'den faydalanılarak değerlendirme puanları hesaplanır.

$H_{i}=\sum_{k=1}^{n} h_{i k}$

Adım 8. Bu adım alternatiflere ait sıralamanın gerçekleştirilmesi adımıdır. Değerlendirme puanlarının büyükten küçüğe doğru sıraya 
konması suretiyle sıralama sonucu elde edilir. Karar problemi için en iyi alternatif en yüksek değerlendirme puanına sahip olan alternatif olarak belirlenir.

\subsection{ROV Yöntemi}

ROV (Range Of Values) yöntemi Değer Aralığı Yöntemi olarak isimlendirilen, Yakowitz vd., tarafından 1993 yılında literatüre kazandırılan bir ÇKKV yöntemidir. Yöntem karar vericiden yalnızca kriter öneminin siralı belirtilmesini gerektirir. Bu sebeple, karar vericilerin kantitatif ağırlıkları sağlamada sorunlarla karşılaştığı durumlarda ROV yöntemi kullanımının özellikle yararlı olduğu belirtilmektedir. Diğer ÇKKV yöntemlerine kıyasla çok basit bir hesaplama prosedürü sunması, kolay uygulanabilirliği ve işlem süresinin kısalığı temel avantajları olarak sıralanabilir. Yöntem 3 adımda uygulanır (Madić, Radovanović ve Manić, 2016: 247-248).

Adım 1. Karar matrisi Eşitlik (1)'de yer aldığ şsekliyle oluşturulur.

Adım 2. Kriter birimleri arasındaki aykırılıkları yok etmek amacıyla normalizasyon işlemi gerçekleştirilir. Bu adımında maksimizasyon yönlü fayda nitelikli kriterler için Eşitlik (2), minimizasyon yönlü maliyet nitelikli kriterler için ise Eşitlik (3) kullanılır.

Adım 3. Her alternatife yönelik en iyi fayda $\left(u_{i}^{+}\right)$ve en kötü fayda $\left(u_{i}^{-}\right)$değerleri hesabı gerçekleştirilir. En iyi fayda değerinin hesabında fayda nitelikli kriterler değerlemeye alınırken, en kötü fayda değerinin hesabında ise maliyet nitelikli kriterler değerlemeye alınır. Bu hesaplamalar Eşitlik (18) ve Eşitlik (19)'da gösterildiği gibidir.

$u_{i}^{+}=\sum_{j=1}^{n} r_{i j} * w_{j}$

$u_{i}^{-}=\sum_{j=1}^{n} r_{i j} * w_{j}$

Alternatiflerin sıralamasını elde edebilmek adına Eşitlik (20)'de gösterildiği gibi orta noktadan hesaplanan bir puanlama $\left(u_{i}\right)$ elde edilir.

$u_{i}=\frac{u_{i}^{+}+u_{i}^{-}}{2}$ 
Siralama esnasında en yüksek $u_{i}$ değerine sahip olan alternatif en iyi alternatif olarak belirlenirken, en düşük $u_{i}$ değerine sahip olan alternatif en kötü alternatif olarak belirlenir.

\section{Bulgular}

Çalışmanın bu bölümünde Avrupa Birliği (AB) üye ülkeleri yaşam kalitesi çok kriterli karar verme (ÇKKV) teknikleri kullanılarak analize tabi tutulmuştur. Ülkelere ait yaşam kalitesi değerlendirme sürecinde 8 adet kriter esas alınmıştır. Kriterlere ait açıklamalar Tablo 1'de yer almaktadır. Analiz sürecinde veriler Numbeo adlı internet sitesinden edinilmiş olup, 2020 yılı kasım ayı değerleridir.

Tablo 1: Değerlendirme Kriterleri

\begin{tabular}{ccl}
\hline Kriterin Kodu & Kriterin Türü & \multicolumn{1}{c}{ Kriterin Ad1 } \\
\hline YKK1 & Max & Satınalma gücü indeksi \\
YKK2 & Max & Güvenlik indeksi \\
YKK3 & Max & Sağlık hizmeti indeksi \\
YKK4 & Max & İklim indeksi \\
YKK5 & Min & Yaşam maliyeti indeksi \\
YKK6 & Min & Emlak fiyatları gelir oranı \\
YKK7 & Min & Trafikte harcanan süre indeksi \\
YKK8 & Min & Kirlilik indeksi \\
\hline
\end{tabular}

Kriter ağırlıklarının belirlenmesi aşamasında CRITIC yöntemi kullanılmıştır. Öznel ağırlıklandırma yaklaşımlarının karar vericilere ait değerlendirme ve yargıları yansıtması ve buna müteakiben bu yargıların sıklıkla belirsizlik içermesi ve sayısal hale dönüştürülmesinin zorluğu sebebiyle bu yöntemin kullanımı uygun görülmüştür. Ülkelerin yaşam kalitesi açısından sıralaması ise literatürde kısmen yeni olan CODAS yöntemi ve uzun yıllardır pek çok uygulamada geçerliliğini kanitlayan ROV yöntemi ile gerçekleştirilmiştir. Her iki yönteme ait uygulamalar sonucunda elde edilen siralamalar ülkelere ait QLI (quality life index) siralaması ile karşılaştırılmış ve bu bağlamda iki yöntemin başarı düzeyinin kıyası da mümkün olmuştur.

\subsection{CRITIC Yöntemi ile Kriter Ağırlıklarının Hesaplanması}

Veriler ile Tablo 2' de sunulan karar matrisi oluşturulmuştur. 
Tablo 2: Karar Matrisi

\begin{tabular}{|c|c|c|c|c|c|c|c|c|}
\hline & $\max$ & $\max$ & $\max$ & $\max$ & $\min$ & $\min$ & $\min$ & Min \\
\hline ÜLKE & YKK1 & YKK2 & YKK3 & YKK4 & YKK5 & YKK6 & YKK7 & YKK8 \\
\hline Almanya & 93.53 & 64.65 & 73.75 & 82.97 & 70.78 & 9.00 & 31.42 & 27.48 \\
\hline Avusturya & 77.88 & 74.79 & 78.40 & 77.79 & 76.14 & 10.47 & 25.82 & 19.20 \\
\hline Belçika & 76.09 & 56.06 & 75.14 & 86.03 & 78.83 & 6.96 & 36.41 & 50.89 \\
\hline Bulgaristan & 40.05 & 61.85 & 56.33 & 82.76 & 41.18 & 9.00 & 29.49 & 64.45 \\
\hline Çek Cum. & 55.70 & 74.69 & 75.29 & 77.13 & 49.17 & 15.5 & 29.76 & 36.30 \\
\hline Danimarka & 95.70 & 73.47 & 79.96 & 81.80 & 91.74 & 6.63 & 28.65 & 20.40 \\
\hline Estonya & 60.98 & 76.77 & 72.71 & 64.28 & 56.45 & 9.14 & 24.62 & 18.96 \\
\hline Finlandiya & 89.80 & 73.40 & 76.55 & 56.64 & 77.75 & 8.52 & 28.96 & 11.63 \\
\hline Fransa & 73.39 & 51.06 & 81.03 & 89.94 & 81.16 & 13.54 & 34.61 & 41.81 \\
\hline GKRY & 51.97 & 68.09 & 52.39 & 93.34 & 64.74 & 7.10 & 23.58 & 56.73 \\
\hline Hirvatistan & 40.62 & 75.06 & 64.03 & 89.69 & 59.75 & 14.45 & 28.13 & 30.48 \\
\hline Hollanda & 83.37 & 72.68 & 75.64 & 87.11 & 79.20 & 7.36 & 27.69 & 25.32 \\
\hline İrlanda & 73.25 & 54.76 & 52.58 & 89.13 & 84.02 & 7.36 & 37.79 & 33.69 \\
\hline İspanya & 63.24 & 67.21 & 78.81 & 93.18 & 59.11 & 9.63 & 29.31 & 39.45 \\
\hline İsveç & 90.43 & 52.72 & 68.76 & 74.92 & 78.48 & 8.48 & 29.89 & 18.44 \\
\hline İtalya & 58.70 & 55.82 & 66.85 & 91.21 & 73.49 & 9.50 & 34.21 & 53.86 \\
\hline Letonya & 46.06 & 62.90 & 62.18 & 74.70 & 53.10 & 8.49 & 31.16 & 33.85 \\
\hline Litvanya & 54.06 & 65.92 & 71.05 & 69.86 & 48.29 & 11.07 & 25.67 & 27.01 \\
\hline Lüksemburg & 93.62 & 67.84 & 72.57 & 82.62 & 89.07 & 12.30 & 31.83 & 23.27 \\
\hline Macaristan & 49.24 & 65.08 & 50.36 & 79.48 & 43.63 & 11.66 & 35.81 & 48.11 \\
\hline Malta & 42.19 & 61.07 & 67.12 & 97.44 & 73.74 & 12.32 & 29.73 & 77.84 \\
\hline Polonya & 47.39 & 71.05 & 59.19 & 76.03 & 42.80 & 13.89 & 31.34 & 53.29 \\
\hline Portekiz & 45.03 & 70.21 & 71.87 & 97.72 & 53.26 & 12.35 & 29.66 & 29.51 \\
\hline Romanya & 44.70 & 71.71 & 55.99 & 77.62 & 38.63 & 10.70 & 34.24 & 58.46 \\
\hline Slovakya & 49.99 & 70.39 & 60.78 & 78.13 & 49.35 & 11.39 & 27.97 & 39.06 \\
\hline Slovenya & 56.43 & 78.95 & 65.25 & 77.56 & 59.52 & 10.77 & 26.87 & 22.75 \\
\hline Yunanistan & 38.67 & 56.15 & 56.95 & 94.18 & 61.67 & 10.19 & 33.87 & 51.94 \\
\hline
\end{tabular}

Fayda kriterleri için Eşitlik (2), maliyet kriterleri için Eşitlik (3) kullanılarak karar matrisinin normalizasyonu gerçekleştirilmiş ve Tablo 3' de yer alan normalize edilmiş karar matrisine ulaşılmıştır. 
Tablo 3: Normalize Karar Matrisi

\begin{tabular}{|c|c|c|c|c|c|c|c|c|}
\hline ÜLKE & YKK1 & YKK2 & YKK3 & YKK4 & YKK5 & YKK6 & YKK7 & YKK8 \\
\hline Almanya & 0.9619 & 0.4873 & 0.7626 & 0.6409 & 0.3947 & 0.7328 & 0.4483 & 0.7606 \\
\hline Avusturya & 0.6875 & 0.8508 & 0.9142 & 0.5148 & 0.2937 & 0.5671 & 0.8424 & 0.8857 \\
\hline Belçika & 0.6561 & 0.1793 & 0.8080 & 0.7154 & 0.2431 & 0.9628 & 0.0971 & 0.4070 \\
\hline Bulgaristan & 0.0242 & 0.3869 & 0.1947 & 0.6358 & 0.9520 & 0.7328 & 0.5841 & 0.2022 \\
\hline Çek Cum. & 0.2986 & 0.8473 & 0.8128 & 0.4988 & 0.8015 & 0.0000 & 0.5651 & 0.6274 \\
\hline Danimarka & 1.0000 & 0.8035 & 0.9651 & 0.6125 & 0.0000 & 1.0000 & 0.6432 & 0.8675 \\
\hline Estonya & 0.3912 & 0.9218 & 0.7287 & 0.1860 & 0.6645 & 0.7170 & 0.9268 & 0.8893 \\
\hline Finlandiya & 0.8965 & 0.8010 & 0.8539 & 0.0000 & 0.2634 & 0.7869 & 0.6214 & 1.0000 \\
\hline Fransa & 0.6088 & 0.0000 & 1.0000 & 0.8106 & 0.1992 & 0.2210 & 0.2238 & 0.5442 \\
\hline GKRY & 2332 & 0.6106 & 0.0662 & 0.8934 & 0.5084 & 0.9470 & 1.0000 & 0.3188 \\
\hline Hirvatistan & 0.0342 & 0.8605 & 0.4457 & 0.8045 & 0.6023 & 0.1184 & 0.6798 & 0.7153 \\
\hline Hollanda & 0.7838 & 0.7752 & 0.8243 & 0.7417 & 0.2361 & 0.9177 & 0.7108 & 0.7932 \\
\hline İrlanda & 0.6063 & 0.1327 & 0.0724 & 0.7909 & 0.1454 & 0.9177 & 0.0000 & 0.6668 \\
\hline İspanya & 0.4308 & 0.5791 & 0.9276 & 0.8895 & 0.6144 & 0.6618 & 0.5968 & 0.5798 \\
\hline İsveç & 0.9076 & 0.0595 & 0.5999 & 0.4450 & 0.2497 & 0.7914 & 0.5559 & 0.8971 \\
\hline İtalya & 0.3512 & 0.1707 & 0.5377 & 0.8415 & 0.3436 & 0.6764 & 0.2519 & 0.3622 \\
\hline Letonya & 0.1296 & 0.4245 & 0.3854 & 0.4396 & 0.7275 & 0.7903 & 0.4666 & 0.6644 \\
\hline Litvanya & 0.2699 & 0.5328 & 0.6746 & 0.3218 & 0.8181 & 0.4994 & 0.8529 & 0.7677 \\
\hline Lüksemburg & 0.9635 & 0.6016 & 0.7242 & 0.6324 & 0.0503 & 0.3608 & 0.4194 & 0.8242 \\
\hline Macaristan & 0.1853 & 0.5027 & 0.0000 & 0.5560 & 0.9059 & 0.4329 & 0.1393 & 0.4490 \\
\hline Malta & 0.0617 & 0.3589 & 0.5465 & 0.9932 & 0.3389 & 0.3585 & 0.5672 & 0.0000 \\
\hline Polonya & 0.1529 & 0.7167 & 0.2879 & 0.4720 & 0.9215 & 0.1815 & 0.4539 & 0.3708 \\
\hline Portekiz & 0.1115 & 0.6866 & 0.7013 & 1.0000 & 0.7245 & 0.3551 & 0.5721 & 0.7300 \\
\hline Romanya & 0.1057 & 0.7404 & 0.1836 & 0.5107 & 1.0000 & 0.5411 & 0.2498 & 0.2927 \\
\hline Slovakya & 0.1985 & 0.6931 & 0.3397 & 0.5231 & 0.7982 & 0.4634 & 0.6911 & 0.5857 \\
\hline Slovenya & 0.3114 & 1.0000 & 0.4855 & 0.5093 & 0.6067 & 0.5333 & 0.7685 & 0.8320 \\
\hline Yunanistan & 0.0000 & 0.1825 & 0.2149 & 0.9138 & 0.5662 & 0.5986 & 0.2759 & 0.3912 \\
\hline Std. Sapma & 0.3325 & 0.2858 & 0.3034 & 0.2402 & 0.2952 & 0.2723 & 0.2568 & 0.2501 \\
\hline
\end{tabular}

Tablo 3' de normalize edilmiş karar matrisi değerlerinin yanı sıra kriterlere ait bilgi miktarı değerlerinin $\left(C_{J}\right)$ hesaplanması için gerekli olan standart sapma $\left(\sigma_{J}\right)$ değerleri de gösterilmiştir. Kriterler arasındaki ilişkinin göstergesi olarak Pearson korelasyon katsayısı değerleri Eşitlik (4)'den faydalanılarak bulunmuştur. Bu değerler Tablo 4' de yer almaktadir. 
Tablo 4: Kriterler Arası Korelasyon Katsayıları

\begin{tabular}{lcccccccc}
\hline & YKK1 & YKK2 & YKK3 & YKK4 & YKK5 & YKK6 & YKK7 & YKK8 \\
\hline YKK1 & 1.000 & -0.05 & 0.612 & -0.254 & -0.786 & 0.424 & -0.029 & 0.630 \\
YKK2 & -0.051 & 1.000 & 0.156 & -0.390 & 0.281 & -0.200 & 0.645 & 0.391 \\
YKK3 & 0.612 & 0.156 & 1.000 & -0.130 & -0.502 & -0.016 & 0.239 & 0.524 \\
YKK4 & -0.254 & -0.390 & -0.130 & 1.000 & -0.177 & -0.068 & -0.270 & -0.521 \\
YKK5 & -0.786 & 0.281 & -0.502 & -0.177 & 1.000 & -0.402 & 0.123 & -0.355 \\
YKK6 & 0.424 & -0.200 & -0.016 & -0.068 & -0.402 & 1.000 & 0.020 & 0.146 \\
YKK7 & -0.029 & 0.645 & 0.239 & -0.270 & 0.123 & 0.020 & 1.000 & 0.343 \\
YKK8 & 0.630 & 0.391 & 0.524 & -0.521 & -0.355 & 0.146 & 0.343 & 1.000 \\
\hline
\end{tabular}

İlerleyen adımda her kriterin içerdiği bilgi miktarı $\left(C_{J}\right)$ Tablo 3' de yer alan standart sapma $\left(\sigma_{J}\right)$ değerleri kullanılarak Eşitlik (5) yardımıyla hesaplanmıştır. Son adımda ise her bir kritere ait $\left(C_{J}\right)$ değeri kriterlerin $\left(C_{J}\right)$ değerlerinin toplamına oranlanarak kriter ağırlıkları $\left(w_{j}\right)$ hesaplanmıştır (Eşitlik (7)). Kriterlerin bilgi miktarları ve hesaplanan kriter ağırlık değerleri Tablo 5'de verilmiştir.

Tablo 5: Kriterlerin Bilgi Miktarları $\left(C_{J}\right)$ ve Kriter Ağırlıkları $\left(w_{j}\right)$

\begin{tabular}{lllllllll}
\hline & YKK1 & YKK2 & YKK3 & YKK4 & YKK5 & YKK6 & YKK7 & YKK8 \\
\hline $\boldsymbol{C}_{\boldsymbol{J}}$ & 2.1462 & 1.7623 & 1.8556 & 2.1170 & 2.6030 & 1.9323 & 1.5226 & 1.4610 \\
$\boldsymbol{w}_{\boldsymbol{J}}$ & 0.1394 & 0.1144 & 0.1205 & 0.1375 & 0.1690 & 0.1255 & 0.0989 & 0.0949 \\
\hline
\end{tabular}

CRITIC yöntemi ile elde edilen sonuçlar ülkelerin yaşam kalitesi analizinde en fazla önem arz eden kriterin yaşam maliyeti indeksi (YKK5) olduğuna işaret etmektedir. En az önem arz eden kriter ise kirlilik indeksi (YKK8) olarak belirlenmiştir. Bu kriter ağırlık değerleri CODAS ve ROV yöntemleri içerisinde kullanılacaktır.

\subsection{CODAS Yöntemi ile Ülkelerin Yaşam Kalitesi Analizi}

Başlangıç karar matrisi Tablo 2'de yer almaktadır. Eşitlik (8) ve Eşitlik (9) kullanımı ile bu matris normalize edilerek Tablo $6{ }^{\prime}$ da verilen normalleştirilmiş karar matrisi elde edilmiştir. 
Tablo 6: Normalize Karar Matrisi

\begin{tabular}{|c|c|c|c|c|c|c|c|c|}
\hline ÜLKE & YKK1 & YKK2 & YKK3 & YKK4 & YKK5 & YKK6 & YKK7 & YKK8 \\
\hline Almanya & 0.9773 & 0.8189 & 0.9102 & 0.8491 & 0.5458 & 0.7367 & 0.7505 & 0.4232 \\
\hline Avusturya & 0.8138 & 0.9473 & 0.9675 & 0.7960 & 0.5074 & 0.6332 & 0.9132 & 0.6057 \\
\hline Belçika & 0.7951 & 0.7101 & 0.9273 & 0.8804 & 0.4900 & 0.9526 & 0.6476 & 0.2285 \\
\hline Bulgaristan & 0.4185 & 0.7834 & 0.6952 & 0.8469 & 0.9381 & 0.7367 & 0.7996 & 0.1804 \\
\hline Çek Cum. & 0.5820 & 0.9460 & 0.9292 & 0.7893 & 0.7856 & 0.4277 & 0.7923 & 0.3204 \\
\hline Danimarka & 1.0000 & 0.9306 & 0.9868 & 0.8371 & 0.4211 & 1.0000 & 0.8230 & 0.5701 \\
\hline Estonya & 0.6372 & 0.9724 & 0.8973 & 0.6578 & 0.6843 & 0.7254 & 0.9578 & 0.6134 \\
\hline Finlandiya & 0.9383 & 0.9297 & 0.9447 & 0.5796 & 0.4968 & 0.7782 & 0.8142 & 1.0000 \\
\hline Fransa & 0.7669 & 0.6467 & 1.0000 & 0.9204 & 0.4760 & 0.4897 & 0.6813 & 0.2782 \\
\hline GKRY & 0.5431 & 0.8624 & 0.6466 & 0.9552 & 0.5967 & 0.9338 & 1.0000 & 0.2050 \\
\hline Hirvatistan & 0.4245 & 0.9507 & 0.7902 & 0.9178 & 0.6465 & 0.4588 & 0.8383 & 0.3816 \\
\hline Hollanda & 0.8712 & 0.9206 & 0.9335 & 0.8914 & 0.4878 & 0.9008 & 0.8516 & 0.4593 \\
\hline İrlanda & 0.7654 & 0.6936 & 0.6489 & 0.9121 & 0.4598 & 0.9008 & 0.6240 & 0.3452 \\
\hline İspanya & 0.6608 & 0.8513 & 0.9726 & 0.9535 & 0.6535 & 0.6885 & 0.8045 & 0.2948 \\
\hline İsveç & 0.9449 & 0.6678 & 0.8486 & 0.7667 & 0.4922 & 0.7818 & 0.7889 & 0.6307 \\
\hline İtalya & 0.6134 & 0.7070 & 0.8250 & 0.9334 & 0.5256 & 0.6979 & 0.6893 & 0.2159 \\
\hline Letonya & 0.4813 & 0.7967 & 0.7674 & 0.7644 & 0.7275 & 0.7809 & 0.7567 & 0.3436 \\
\hline Litvanya & 0.5649 & 0.8350 & 0.8768 & 0.7149 & 0.8000 & 0.5989 & 0.9186 & 0.4306 \\
\hline Lüksemburg & 0.9783 & 0.8593 & 0.8956 & 0.8455 & 0.4337 & 0.5390 & 0.7408 & 0.4998 \\
\hline Macaristan & 0.5145 & 0.8243 & 0.6215 & 0.8133 & 0.8854 & 0.5686 & 0.6585 & 0.2417 \\
\hline Malta & 0.4409 & 0.7735 & 0.8283 & 0.9971 & 0.5239 & 0.5381 & 0.7931 & 0.1494 \\
\hline Polonya & 0.4952 & 0.8999 & 0.7305 & 0.7780 & 0.9026 & 0.4773 & 0.7524 & 0.2182 \\
\hline Portekiz & 0.4705 & 0.8893 & 0.8870 & 1.0000 & 0.7253 & 0.5368 & 0.7950 & 0.3941 \\
\hline Romanya & 0.4671 & 0.9083 & 0.6910 & 0.7943 & 1.0000 & 0.6196 & 0.6887 & 0.1989 \\
\hline Slovakya & 0.5224 & 0.8916 & 0.7501 & 0.7995 & 0.7828 & 0.5821 & 0.8430 & 0.2977 \\
\hline Slovenya & 0.5897 & 1.0000 & 0.8053 & 0.7937 & 0.6490 & 0.6156 & 0.8776 & 0.5112 \\
\hline Yunanistan & 0.4041 & 0.7112 & 0.7028 & 0.9638 & 0.6264 & 0.6506 & 0.6962 & 0.2239 \\
\hline
\end{tabular}

Üçüncü adımında Eşitlik (10) ile ifade edildiği üzere normalize karar matrisi ağırlıklıklandırılmış ve Tablo 7 'de gösterildiği şekilde ağırlıklandırılmış normalize karar matrisi haline dönüştürülmüştür. 
Tablo 7: Ağırlıklandırılmış Normalize Karar Matrisi

\begin{tabular}{|c|c|c|c|c|c|c|c|c|c|c|}
\hline ÜLKE & $\frac{\vec{z}}{2}$ & $\frac{\mathbb{v}}{2}$ & $\frac{\partial}{2}$ & $\frac{\mathbb{z}}{z}$ & $\frac{10}{2}$ & $\frac{\vartheta}{z}$ & $\frac{v}{2}$ & $\underset{⿱ 亠 乂}{\infty}$ & $\tilde{y}$ & $\ddot{H}$ \\
\hline Almanya & 0.136 & 0.093 & 0.109 & 0.116 & 0.092 & 0.092 & 0.074 & 0.040 & 0.110 & 0.269 \\
\hline Avusturya & 0.113 & 0.108 & 0.116 & 0.109 & 0.085 & 0.079 & 0.090 & 0.057 & 0.103 & 0.275 \\
\hline Belçika & 0.110 & 0.081 & 0.111 & 0.121 & 0.082 & 0.119 & 0.064 & 0.021 & 0.103 & 0.227 \\
\hline Bulgaristan & 0.058 & 0.089 & 0.083 & 0.116 & 0.158 & 0.092 & 0.079 & 0.017 & 0.105 & 0.209 \\
\hline Çek Cum. & 0.081 & 0.108 & 0.112 & 0.108 & 0.132 & 0.053 & 0.078 & 0.030 & 0.091 & 0.219 \\
\hline Danimarka & 0.139 & 0.106 & 0.118 & 0.115 & 0.071 & 0.125 & 0.081 & 0.054 & 0.135 & 0.326 \\
\hline Estonya & 0.088 & 0.111 & 0.108 & 0.090 & 0.115 & 0.091 & 0.094 & 0.058 & 0.100 & 0.272 \\
\hline Finlandiya & 0.130 & 0.106 & 0.113 & 0.079 & 0.084 & 0.097 & 0.080 & 0.094 & 0.130 & 0.302 \\
\hline Fransa & 0.106 & 0.074 & 0.120 & 0.126 & 0.080 & 0.061 & 0.067 & 0.026 & 0.084 & 0.177 \\
\hline GKRY & 0.075 & 0.098 & 0.077 & 0.131 & 0.100 & 0.117 & 0.098 & 0.019 & 0.099 & 0.234 \\
\hline Hirvatistan & 0.059 & 0.108 & 0.095 & 0.126 & 0.109 & 0.057 & 0.082 & 0.036 & 0.078 & 0.189 \\
\hline Hollanda & 0.121 & 0.105 & 0.112 & 0.122 & 0.082 & 0.113 & 0.084 & 0.043 & 0.116 & 0.299 \\
\hline İrlanda & 0.106 & 0.079 & 0.078 & 0.125 & 0.077 & 0.113 & 0.061 & 0.032 & 0.092 & 0.189 \\
\hline İspanya & 0.092 & 0.097 & 0.117 & 0.131 & 0.110 & 0.086 & 0.079 & 0.028 & 0.096 & 0.256 \\
\hline İsveç & 0.131 & 0.076 & 0.102 & 0.105 & 0.083 & 0.098 & 0.078 & 0.059 & 0.107 & 0.249 \\
\hline İtalya & 0.085 & 0.080 & 0.099 & 0.128 & 0.088 & 0.087 & 0.068 & 0.020 & 0.073 & 0.173 \\
\hline Letonya & 0.067 & 0.091 & 0.092 & 0.105 & 0.123 & 0.098 & 0.074 & 0.032 & 0.080 & 0.198 \\
\hline Litvanya & 0.078 & 0.095 & 0.105 & 0.098 & 0.135 & 0.075 & 0.090 & 0.040 & 0.091 & 0.234 \\
\hline Lüksemburg & 0.136 & 0.098 & 0.107 & 0.116 & 0.073 & 0.067 & 0.073 & 0.047 & 0.104 & 0.234 \\
\hline Macaristan & 0.071 & 0.094 & 0.074 & 0.111 & 0.149 & 0.071 & 0.065 & 0.022 & 0.090 & 0.176 \\
\hline Malta & 0.061 & 0.088 & 0.099 & 0.137 & 0.088 & 0.067 & 0.078 & 0.014 & 0.070 & 0.149 \\
\hline Polonya & 0.069 & 0.103 & 0.088 & 0.107 & 0.152 & 0.059 & 0.074 & 0.020 & 0.093 & 0.188 \\
\hline Portekiz & 0.065 & 0.101 & 0.106 & 0.137 & 0.122 & 0.067 & 0.078 & 0.037 & 0.094 & 0.232 \\
\hline Romanya & 0.065 & 0.103 & 0.083 & 0.109 & 0.169 & 0.077 & 0.068 & 0.018 & 0.110 & 0.209 \\
\hline Slovakya & 0.072 & 0.102 & 0.090 & 0.109 & 0.132 & 0.073 & 0.083 & 0.028 & 0.083 & 0.206 \\
\hline Slovenya & 0.082 & 0.114 & 0.097 & 0.109 & 0.109 & 0.077 & 0.086 & 0.048 & 0.086 & 0.239 \\
\hline Yunanistan & 0.056 & 0.081 & 0.084 & 0.132 & 0.105 & 0.081 & 0.068 & 0.021 & 0.070 & 0.146 \\
\hline $\begin{array}{l}\text { Negatif İdeal } \\
\text { Çözüm }\end{array}$ & 0 & 74 & 0 & 0 & 71 & 0 & 0 & 4 & - & 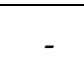 \\
\hline
\end{tabular}

Dördüncü adımda yer alan Eşitlik (11) ile ağırlıklandırılmış normalize karar matrisinin her sütünü için minimum değerler belirlenerek, kriterlere ait negatif ideal çözüm değerleri de tabloya eklenmiştir. Aynı zamanda bu tabloda yer alan $E_{i}$ Öklid uzaklığı ve $T_{i}$ Taxicab uzaklığı beşinci adımda yer alan ve Eşitlik (12) ve Eşitlik (13) denklemleri ile ifade edilen formüller yardımıyla hesaplanmıştır. Bir sonraki göreceli değerlendirme matrisinin oluşturulması aşamasında Öklid ve Taxicab uzaklık değerleri esas alınmıştır.

Göreceli değerlendirme matris elemanlarının hesaplandığı altıncı adımda Eşitlik (15)'den faydalanılmıştır. Hesaplama sürecinde Eşitlik 
(16)'da tanımlanmış olan ve Taxicab $\left(T_{i}\right)$ uzaklığının hangi durumlarda hesaba katılması gerektiğini ifade eden eşik fonksiyonu içerisindeki $\tau$ değeri önceki çalışmalarda olduğu gibi (Ghorabaee vd., 2016; Badi, Abdulshahed ve Shetwan, 2018; Boltürk, 2018; Mathew ve Sahu, 2018; Kiracı ve Bakır, 2020) bu çalışmada da 0.02 olarak analize dahil edilmiştir.

Adım 7 her bir karar alternatifi için değerlendirme puanının $\left(H_{i}\right)$ hesaplanmasını içermektedir. Eşitlik (17)'den faydalanılarak değerlendirme puanları hesaplanmış ve Tablo 8'de gösterilmiştir. Değerlendirme puanlarının büyükten küçüğe doğru sıraya konması suretiyle sıralama sonucu elde edilmiş ve aynı tabloda paylaşılmıştır.

Karar problemi için en yüksek değerlendirme puanına sahip ülke olan Danimarka en iyi alternatif olarak belirlenmiştir. Sıralamada Danimarka'yı, Finlandiya ve Hollanda izlemektedir. Sonuçlar yaşam kalitesi açısından en geride yer alan ülkenin ise Yunanistan olduğuna işaret etmektedir.

Tablo 8: Değerlendirme Puanları $\left(H_{i}\right)$ ve Sıralama

\begin{tabular}{|c|c|c|c|c|c|c|c|c|}
\hline ÜLKE & $\ddot{I}$ & कँ & ÜLKE & $\ddot{I}$ & कึ & ÜLKE & $\ddot{I}$ & के \\
\hline Almanya & 0.864 & 4 & GKRY & 0.203 & 12 & Lüksemburg & 0.349 & 8 \\
\hline Avusturya & 0.605 & 6 & Hirvatistan & -1.259 & 24 & Macaristan & -0.515 & 20 \\
\hline Belçika & 0.268 & 10 & Hollanda & 1.867 & 3 & Malta & -2.357 & 26 \\
\hline Bulgaristan & 0.237 & 11 & İrlanda & -0.375 & 18 & Polonya & -0.333 & 17 \\
\hline Çek Cum. & -0.257 & 16 & İspanya & 0.193 & 13 & Portekiz & -0.062 & 14 \\
\hline Danimarka & 3.401 & 1 & İsveç & 0.615 & 5 & Romanya & 0.323 & 9 \\
\hline Estonya & 0.443 & 7 & İtalya & -1.722 & 25 & Slovakya & -0.768 & 21 \\
\hline Finlandiya & 2.754 & 2 & Letonya & -1.000 & 23 & Slovenya & -0.496 & 19 \\
\hline Fransa & -0.885 & 22 & Litvanya & -0.174 & 15 & Yunanistan & -2.364 & 27 \\
\hline
\end{tabular}

\subsection{ROV Yöntemi ile Ülkelerin Yaşam Kalitesi Analizi}

ROV yöntemi ile analizde Tablo 2'de sunulan başlangıç karar matrisi Eşitlik (2) ve Eşitlik (3) kullanımı ile normalize edilerek Tablo 3 'de sunulan normalize karar matrisi tesis edilmiştir.

Öncesinde CRITIC yöntemi ile belirlenen kriter ağırlık değerleri sürece dahil edilerek Eşitlik (18) ve Eşitlik (19)'da gösterildiği gibi her alternatife yönelik en iyi fayda $\left(u_{i}^{+}\right)$ve en kötü fayda $\left(u_{i}^{-}\right)$değerleri 
hesaplanmıştır. En iyi fayda değerinin hesabında fayda nitelikli kriterler (YKK1, YKK2, YKK3 ve YKK4); en kötü fayda değerinin hesabinda ise maliyet nitelikli kriterler (YKK5, YKK6, YKK7 ve YKK8) değerlemeye alınmıştır. Karar alternatiflerinin sıralanması için Eşitlik (20)'de gösterildiği gibi orta noktadan hesaplanan bir puanlama $\left(u_{i}\right)$ elde edilmiştir. $\mathrm{Bu}$ değerler, ortalama puanlar ve sıralama sonuçları Tablo 9' da gösterilmiştir.

ROV yöntemi ile değerlemede en yüksek ortalama puana sahip ülke olan Danimarka en iyi alternatif olarak belirlenmiştir. Sonuçlar yaşam kalitesi açısından en geride yer alan ülkenin Yunanistan olduğuna işaret etmektedir.

Tablo 9: Alternatiflere Ait En İyi, En Kötü ve Ortalama Fayda Değerleri ve Sıralama Sonuçları

\begin{tabular}{|c|c|c|c|c|c|c|c|c|c|}
\hline ÜLKE & + & "21 & $\approx$ & ڤँ & ÜLKE & +2 & "2i & $\approx$ & कै \\
\hline Almanya & 0.370 & 0.275 & 0.322 & 6 & İsveç & 0.267 & 0.282 & 0.274 & 14 \\
\hline Avusturya & 0.374 & 0.288 & 0.331 & 3 & İtalya & 0.249 & 0.202 & 0.226 & 23 \\
\hline Belçika & 0.308 & 0.210 & 0.259 & 17 & Letonya & 0.174 & 0.331 & 0.252 & 18 \\
\hline Bulgaristan & 0.159 & 0.330 & 0.244 & 19 & Litvanya & 0.224 & 0.358 & 0.291 & 10 \\
\hline Çek Cum. & 0.305 & 0.251 & 0.278 & 12 & Lüksemburg & 0.377 & 0.173 & 0.275 & 13 \\
\hline Danimarka & 0.432 & 0.271 & 0.352 & 1 & Macaristan & 0.160 & 0.264 & 0.212 & 24 \\
\hline Estonya & 0.273 & 0.378 & 0.326 & 5 & Malta & 0.252 & 0.158 & 0.205 & 26 \\
\hline Finlandiya & 0.320 & 0.300 & 0.310 & 7 & Polonya & 0.203 & 0.259 & 0.231 & 21 \\
\hline Fransa & 0.317 & 0.135 & 0.226 & 22 & Portekiz & 0.316 & 0.293 & 0.304 & 9 \\
\hline GKRY & 0.233 & 0.334 & 0.284 & 11 & Romanya & 0.192 & 0.289 & 0.241 & 20 \\
\hline Hirvatistan & 0.268 & 0.252 & 0.260 & 16 & Slovakya & 0.220 & 0.317 & 0.268 & 15 \\
\hline Hollanda & 0.399 & 0.301 & 0.350 & 2 & Slovenya & 0.286 & 0.324 & 0.305 & 8 \\
\hline İrlanda & 0.217 & 0.203 & 0.210 & 25 & Yunanistan & 0.172 & 0.235 & 0.204 & 27 \\
\hline İspanya & 0.360 & 0.301 & 0.331 & 4 & & & & & \\
\hline
\end{tabular}

\subsection{Entropi/CODAS ve Entropi/ROV Sıralama Sonuçlarının QLI Siralaması ile Kıyası}

Analizin son aşamasında Entropi/CODAS ve Entropi/ROV yöntemleri ile elde edilen sıralamalar ülkelere ait QLI değerleri sıralaması ile kıyaslanmıştır. Ülkelere ait QLI değerleri Tablo 10'da yer almakta olup, Numbeo isimli internet sitesi tarafından hesaplanmış değerleri içermektedir. 
Entropi/CODAS siralaması ile QLI siralaması arasındaki korelasyon katsayısı 0.71 olarak hesaplanırken, Entropi/ROV sıralaması ile QLI siralaması arasındaki korelasyon katsayısı 0.85 olarak belirlenmiştir. Bu durum ROV yöntemi ile elde edilen sıralama sonuçlarının QLI değerlerini daha iyi yansıttığı düşüncesini beraberinde getirmektedir.

Tablo 10: Sıralama Sonuçları Karşılaştırma

\begin{tabular}{|c|c|c|c|c|c|c|c|c|c|}
\hline ÜLKE & QLI & $\begin{array}{l}\text { QLI } \\
\text { sira }\end{array}$ & $\begin{array}{l}\text { Ent./ } \\
\text { C. } \\
\text { Sira }\end{array}$ & $\begin{array}{c}\text { Ent./ } \\
\text { R. } \\
\text { Sira }\end{array}$ & ÜLKE & QLI & $\begin{array}{l}\text { QLI } \\
\text { sira }\end{array}$ & $\begin{array}{c}\text { Ent./ } \\
\text { C. } \\
\text { Sira }\end{array}$ & $\begin{array}{c}\text { Ent./ } \\
\text { R. } \\
\text { Sira }\end{array}$ \\
\hline Almanya & 176.8 & 5 & 4 & 6 & İsveç & 171.4 & 8 & 5 & 14 \\
\hline Avusturya & 182.0 & 4 & 6 & 3 & İtalya & 138.7 & 21 & 25 & 23 \\
\hline Belçika & 150.2 & 17 & 10 & 17 & Letonya & 147.7 & 19 & 23 & 18 \\
\hline Bulgaristan & 126.2 & 26 & 11 & 19 & Litvanya & 159.6 & 12 & 15 & 10 \\
\hline Çek Cum. & 156.0 & 13 & 16 & 12 & Lüksemburg & 175.3 & 6 & 8 & 13 \\
\hline Danimarka & 190.5 & 1 & 1 & 1 & Macaristan & 132.9 & 23 & 20 & 24 \\
\hline Estonya & 173.6 & 7 & 7 & 5 & Malta & 120.3 & 27 & 26 & 26 \\
\hline Finlandiya & 183.6 & 2 & 2 & 7 & Polonya & 134.1 & 22 & 17 & 21 \\
\hline Fransa & 150.4 & 15 & 22 & 22 & Portekiz & 162.3 & 11 & 14 & 9 \\
\hline GKRY & 143.7 & 20 & 12 & 11 & Romanya & 131.4 & 24 & 9 & 20 \\
\hline Hurvatistan & 154.5 & 14 & 24 & 16 & Slovakya & 149.2 & 18 & 21 & 15 \\
\hline Hollanda & 183.0 & 3 & 3 & 2 & Slovenya & 168.7 & 9 & 19 & 8 \\
\hline İrlanda & 150.3 & 16 & 18 & 25 & Yunanistan & 129.8 & 25 & 27 & 27 \\
\hline İspanya & 165.0 & 10 & 13 & 4 & & & & & \\
\hline
\end{tabular}

\section{Sonuç ve Değerlendirme}

Günümüzde toplumların ulaşmak noktasında çaba gösterdiği evrensel hedefler arasında yer alan yüksek yaşam kalitesi pek çok faktörün etkisi altında olan bir kavramdır. Bu bağlamda ülkelere ait değerlendirmenin yapılabilmesi bir kriter fonksiyonları kümesinin esas alınarak alternatiflerin sıralanmasını gerektirir. Bu süreç ise çok kriterli sıralama yöntemleri kullanılarak gerçekleştirilebilir.

Çalışmada Avrupa Birliği (AB) üye ülkeleri yaşam kalitesi çok kriterli karar verme (ÇKKV) yöntemlerinden CRITIC, CODAS ve ROV yöntemleri kullanımı ile analize tabi tutulmuştur. Ülkelere ait yaşam kalitesi değerlendirme sürecinde satın alma gücü indeksi, iklim indeksi, yaşam maliyeti indeksi, güvenlik indeksi, sağlik hizmeti indeksi, emlak fiyatları/gelir oranı, kirlilik indeksi ve trafikte harcanan süre indeksi kriterleri dikkate alınmıştır. Kriter ağırlıklarının saptanması aşamasında CRITIC yöntemi kullanılmış ve yaşam kalitesi 
değerlendirme sürecine ait en fazla önem arz eden kriterin yaşam maliyeti indeksi olduğu belirlenmiştir. Ülkelerin yaşam kalitesi açısından değerlendirilmesi aşamasında ise CODAS ve ROV yöntemlerinin kullanımı tercih edilmiş olup, her iki yöntem ile de yaşam kalitesi açısından en iyi ülkenin Danimarka olduğu sonucuna ulaşılmıştır. Bu sonuç Danimarka'nın yaşam maliyeti indeksi değerinin minimum olması ile örtüşmektedir. Sonuçlar yaşam kalitesi açısından en geride yer alan ülkenin Yunanistan olduğuna işaret etmektedir.

Ülkelerde yaşam kalitesi analizi ve sıralaması özellikle kalkınmaya yönelik çözüm ve stratejilerin oluşturulması noktasında ciddi faydaları beraberinde getirecektir. Bu bağlamda yapılan çalışmanın yaşam kalitesi analizinde sıralamanın gerisinde yer alan ülkeler açısından yol gösterici nitelik taşıması ümit edilmektedir.

Gelecek çalışmalar için değerlemeye alınan ülke sayısı artırılabilir, daha çok sayıda kriter esas alınabilir. Yine kıyaslamanın güçlendirilmesi adına farklı ÇKKV tekniklerinin entegre kullanımı önerilebilir.

Etik Beyanı: Bu çalışmanın tüm hazırlık sürecinde etik kurallara uyulduğunu yazar beyan eder. Aksi bir durumun tespiti halinde Bİ̈BFAD Dergisinin hiçbir sorumluluğu olmayıp, tüm sorumluluk çalışmanın yazarına aittir.

Teşekkür: Gösterdikleri yoğun ilgi ve emeklerinden dolayı BïB̈FAD Dergisi Editör Kurulu'na ve sağladıkları katkılarından dolayı hakemlere teşekkür ederim.

\section{Kaynakça}

Abdali, H., Sahebi, H., \& Pishvaee, M. (2021). The water-energy-foodland nexus at the sugarcane-to-bioenergy supply chain: A sustainable network design model. Computers $\mathcal{E}$ Chemical Engineering, 145, 107-199.

Ahmad, S., Bingöl, S., \& Wakeel, S. (2020). A hybrid multi-criteria decision making method for robot selection in flexible manufacturing system. Middle East Journal of Science, 6(2), 68-77. 
Akbulut, O. Y. (2020). Finansal performans ile pay senedi getirisi arasındaki ilişkinin bütünleşik CRITIC ve Mabac ÇKKV teknikleriyle ölçülmesi: Borsa İstanbul çimento sektörü firmaları üzerine ampirik bir uygulama. Pamukkale Üniversitesi Sosyal Bilimler Enstitüsü Dergisi, (40), 471-488.

Akçakanat, Ö., Aksoy, E., \& Teker, T. (2018). CRITIC ve MDL temelli EDAS yöntemi ile TR-61 bölgesi bankalarının performans değerlendirmesi. Süleyman Demirel Üniversitesi Sosyal Bilimler Enstitüsü Dergisi, 1(32), 1-24.

Akın, N.G. (2019). Makine seçimi probleminde Entropi-ROV ve CRITIC-ROV yöntemlerinin karşılaştırılması. Dumlupınar Üniversitesi Sosyal Bilimler Dergisi, (62), 20-39.

Alioğulları, E., \& Tüysüz, F. (2020). Edas ve Codas yöntemiyle İstanbul ilinin diş ticaret kapasitesinin incelenmesi. Avrupa Bilim ve Teknoloji Dergisi, 240-248.

Altın, H. (2020). Ekonomik özgürlük endeksinin çok kriterli karar verme yöntemleriyle analizi. Uluslararası Ekonomi İşletme ve Politika Dergisi, 4(2), 441-460.

Apan, M., \& Öztel, A. (2020). Girişim sermayesi yatırım ortaklıklarının CRITIC-PROMETHEE bütünleşik karar verme yöntemi ile finansal performans değerlendirmesi: Borsa İstanbul'da bir uygulama. Dumlupınar Üniversitesi Sosyal Bilimler Dergisi, 63, 54-73

Aydın, Y. (2020). Bütünleşik CRITIC ve MAIRCA yöntemleri ile kamu sermayeli bankalarının performans analizi. Finans Ekonomi ve Sosyal Araştırmalar Dergisi, 5(4), 829-841.

Ayyıldız E., \& Demirci, E. (2018). Türkiye'de yer alan şehirlerin yaşam kalitelerinin SWARA entegreli TOPSIS yöntemi ile belirlenmesi. Pamukkale University Journal of Social Sciences Institute, 30, 67-87.

Badi, I., Abdulshahed, A. M., \& Shetwan, A. (2018). A case study of supplier selection for a steelmaking company in Libya by using the Combinative Distance-based ASsessment (CODAS) 
model. Decision Making: Applications in Management and Engineering, 1(1), 1-12.

Badi, I., \& Kridish, M. (2020). Landfill site selection using a novel FUCOM-CODAS model: A case study in Libya. Scientific African, 9, e00537, 1-10.

Boltürk, E. (2018). Pythagorean fuzzy CODAS and its application to supplier selection in a manufacturing firm. Journal of Enterprise Information Management, 31(4), 550-564.

Chatterjee, P., \& Chakraborty, S. (2012). Material selection using preferential ranking methods. Materials \& Design, 35, 384-393.

Deveci, K., Cin, R., \& Kağızman, A. (2020). A modified interval valued intuitionistic fuzzy CODAS method and its application to multi-criteria selection among renewable energy alternatives in Turkey. Applied Soft Computing, 96, 106660.

Diakoulaki, D., Mavrotas, G., \& Papayannakis, L. (1995). Determining objective weights in multiple criteria problems: The critic method. Computers \& Operations Research, 22(7), 763-770.

Donyaii, A., Sarraf, A., Ahmadi, H. (2020). Presenting a new hybrid evolutionary algorithm in optimizing reservoir operation based on new combinative distance-based assessment (CODAS). Journal of Water and Soil Conservation, 27(5), 1-23.

Ghorabaee, M.K., Zavadskas, E.K., Turskis, Z., \& Antucheviciene, J. (2016). A New combinative distance-based assessment (CODAS) method for multi-criteria decision-making. Economic Computation \& Economic Cybernetics Studies \& Research, 50(3), 25-44.

Kaya, P., Cetin, E.I., \& Kuruüzüm, A. (2011). Çok kriterli karar verme ile Avrupa Birligi ve aday ülkelerin yasam kalitesinin analizi. Ekonometri ve İstatistik Dergisi, 13, 80-94.

Kirac1, K., \& Bakır, M. (2020). Evaluation of airlines performance using an integrated CRITIC and CODAS methodology: The case of star alliance member airlines. Studies in Business and Economics, 15(1), 83-99. 
Koçak, H. (2009). Coğrafi bilgi sistemlerinin kentsel yaşam kalitesinin yükseltilmesine etkileri üzerine bir değerlendirme. Dumlupınar Üniversitesi Sosyal Bilimler Dergisi, 25, 141-148.

Lamas, M.I., Castro-Santos, L., \& Rodriguez, C.G. (2020). Optimization of a multiple injection system in a marine diesel engine through a multiple-criteria decision-making approach. Journal of Marine Science and Engineering, 8(11), 946.

Madic, M. \& Radovanović, M. (2015). Ranking of some most commonly used nontraditional machining processes using ROV and CRITIC methods. U.P.B. Sci. Bull., Series D, 77(2), 193-204.

Madić, M., Radovanović, M., \& Manić, M. (2016). Application of the ROV method for the selection of cutting fluids. Decision Science Letters, 5(2), 245-254.

Mathew, M., \& Sahu, S. (2018). Comparison of new multi-criteria decision making methods for matiral handling equipment selection. Management Science Letters, 8(3), 139-150.

Nguyen, T.K.L., Le, H.N., Ngo, V.H., \& Hoang, B.A. (2020). CRITIC method and grey system theory in the study of global electric cars. World Electric Vehicle Journal, 11(4), 79.

Orakçı, E., \& Özdemir, A. (2017). Telafi edici çok kriterli karar verme yöntemleri ile Türkiye ve $\mathrm{AB}$ ülkelerinin insani gelişmişlik düzeylerinin belirlenmesi. Afyon Kocatepe Üniversitesi İktisadi ve İdari Bilimler Fakültesi Dergisi, 19(1), 61-74.

Ömürbek, N., Eren, H. \& Dağ, O. (2017). Entropi-Aras ve EntropiMoosra yöntemleri ile yaşam kalitesi açısından $\mathrm{AB}$ ülkelerinin değerlendirilmesi. Ömer Halisdemir Üniversitesi İktisadi ve İdari Bilimler Fakültesi Dergisi, 10(2), 29-48.

Özdağoğlu, A., \& Keleş, M. K. (2019). Spor yönetimi açısından gri entropi tabanlı ROV yöntemi ile 4 büyük futbol kulübünün finansal performans analizi. Süleyman Demirel Üniversitesi Sosyal Bilimler Enstitüsü Dergisi, (35), 107-123. 
Pacione, M. (2003). Urban environmental quality and human - a social geographical perspective. Landscape and urban planning, 65(1-2), 19-30.

Rahman, T., Mittelhammer, R.C., \& Wandscheider, P. (2005). Measuring the quality of life across countries: A sensitivity analysis of well-being indices (No. 2005/06). WIDER Research Paper.

Remadi, F. D., \& Frikha, H. M. (2020). The Intuitionistic Fuzzy Set FlowSort methodology for green supplier Evaluation. in 2020 International Conference on Decision Aid Sciences and Application (DASA) (pp. 719-725). IEEE.

Sarı, V.İ., \& Kindap, (2018). Türkiye'de kentsel yaşam kalitesi göstergelerinin analizi. Journal of Turkish Court of Accounts/Sayistay Dergisi, (108), 39-72.

Shahrokhi Sardoo, S., \& Nooripoor, M. (2014). Ranking of the districts of jiroft county based on quality of life criteria, using TOPSIS model. Journal of Research and Rural Planning, 3(6), 89-102.

Ulutaş, A. (2020a). New grey integrated model to solve a machine selection problem for a textile company. Fibres $\mathcal{E}$ Textiles in Eastern Europe, 28, 1(139), 20-25.

Ulutaş, A. (2020b) Supplier evaluation with BWM and fuzzy CODAS methods. In Handbook of Research on Recent Perspectives on Management, International Trade and Logistics. pp. 335-351. IGI Global.

Ulutaş, A. (2020c). SWARA tabanlı CODAS yöntemi ile kargo şirketi seçimi. MANAS Sosyal Araştırmalar Dergisi, 9(3), 1640-1647.

Vujičić, M.D., Papić, M.Z., \& Blagojević, M.D. (2017). Comparative analysis of objective techniques for criteria weighing in two MCDM methods on example of an air conditioner selection. Tehnika, 72(3), 422-429.

Wakeel, S., Ahmad, S., Bingol, S., Bashir, M.N., Paçal, T.C., \& Khan, Z.A. (2020). Supplier Selection for High Temperature Die Attach by hybrid Entropy-Range of Value MCDM Technique: 
A Semiconductor Industry. In 2020 21st International Conference on Electronic Packaging Technology (ICEPT) (pp. 1-5). IEEE.

Yakowitz, D. S., Lane, L. J., \& Szidarovszky, F. (1993). Multi-attribute decision making: Dominance with respect to an importance order of the attributes. Applied Mathematics and Computation, 54(2-3), 167-181.

Yıldız, A., Ayyıldız, E., Gümüş, A. T., \& Özkan, C. (2019). Ülkelerin yaşam kalitelerine göre değerlendirilmesi için hibrit pisagor bulanık AHP-TOPSIS metodolojisi: Avrupa Birliği örneği. Avrupa Bilim ve Teknoloji Dergisi, (17), 1383-1391.

Yılmaz, F., \& Söyük, S. (2020). Sağlık risk faktörlerine göre ülkelerin kümelenmesi ve çok kriterli karar verme teknikleriyle sağlık durumu göstergelerinin analizi. Sosyal Güvence, (17), 283-320.

Zaralı, F. (2020). An application on heavy commercial vehicle selection with an integrated approach of CRITIC-CODAS. Current Researches in Economics and Administrative Sciences, 74-87.

https://www.numbeo.com/cost-of-living/, Erişim Tarihi: 15.11.2020. 
